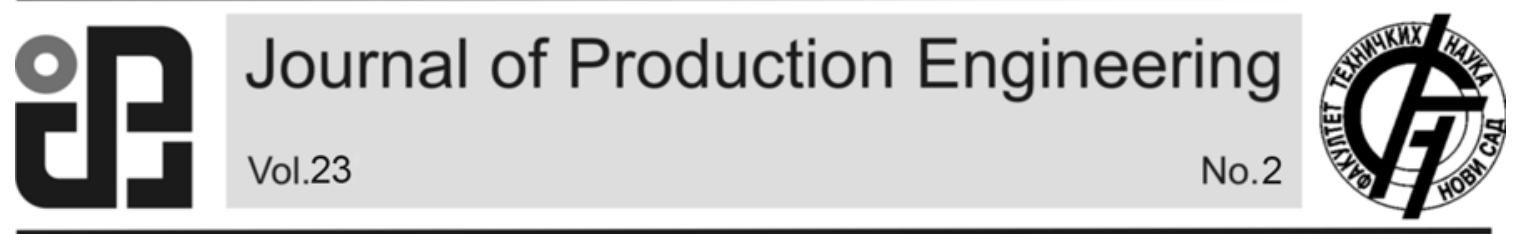

JPE (2020) Vol.23 (2)

Todić, V., Maksimović, R., Ćosić, I.

Original Scientific Paper

\title{
MANAGING TARGET COSTS AT THE DEVELOPMENT STAGE OF A PRODUCT
}

Received: 7 September 2020 / Accepted: 9 November 2020

\begin{abstract}
At the development stage of a product, target cost management has a significant effect on achievement and maintenance of product competitiveness in a given market and the desired target profit as the primary aim of production. Target cost management, i.e., target profit management, is performed by evaluating individual variations of a conceptual and preliminary design solution for a new product and by choosing the solution with the lowest development costs. The paper presents the use of Adaptive Neural Fuzzy Inference System model for managing development costs on the example of double-row angular contact ball bearings as an example of applying the above approach to market positioning in relation to competitors.
\end{abstract}

Key words: Target cost, target profit, development phase, product, Adaptive Neural Fuzzy Inference System.

Upravljanje ciljnim troškovima u fazi razvoja proizvoda. Upravljanje ciljnim troškovima u fazi razvoja proizvoda, ima značajan uticaj na postizanje i održavanje konkurentnosti proizvoda na datom tržištu i postizanje ciljnog profita, kao primarnih ciljeva proizvodnje. Upravljanje ciljnim troškovima, odnosno ciljnim profitom, vrši se procenom pojedinih varijanti idejnog rešenja dizajna novog proizvoda i izborom rě̌enja sa najnižim troškovima razvoja. U radu je prikazana primena adaptivnih neuro-fazi sistema za upravljanje troškovima razvoja proizvoda, na primeru dvorednih kugličnih kotrljajućih ležajeva, kao primer tržišnog pozicioniranja proizvoda u odnosu na konkurente u okruženju..

Ključne reči: Ciljni troškovi, ciljni profit, faza razvoja, proizvod, adaptivni neuro-fazi sistemi.

\section{INTRODUCTION}

The basic characteristics of modern production are related to the high flexibility in terms of adapting the production program to the requirements of the market, as well as producing high-quality products, modern design, low cost and short delivery times. Therefore, the development of modern enterprises is characterized by the development and application of a new generation of integrated, efficient and user-oriented systems for product development processes, as well as the ability of the company to continuously improve its competitive advantage in the global market, taking with it the impact of internal and external factors.

Product development involves a number of activities at creating a market competitive and profitable products. Errors that may arise in the development stage should be eliminated before the production process. Product development process in modern conditions is market-oriented because the product beside functional should indispensably hold other market values such as price, aesthetics, reliability, status symbol, and so on.

Evaluation of alternative design solutions is carried out at the stage of new product development of the conceptual and preliminary design and it is based on the life cycle costs of new products, primarily development costs and production costs known as the target costs. Evaluation of individual variants of conceptual and preliminary construction solutions of a new product and selection of a solution that has the least development and production cost manages controlled target costs, and target profit. Cost management is applied at all stages of the product life cycle, primarily the development stage. Product cost, or target cost management at the development stage enables the manufacturer to maintain market competitiveness, i.e. reach the target profit. Here, at the development stage of the new product, it is necessary to maintain the corresponding technical and functional quality of the product, in addition to the necessary cost reduction of the new product.

In the available literature, a number of models are presented to estimate the product costs which can be classified in specific groups.

Adaptation to consumer needs mass production on the example of food production, i.e. fruit yogurt is described [1]. A modular software platform has been set up and developed with Industry 4.0 standards that apply to this branch of industry. Artificial intelligence is highlighted using nine elements of the Industry 4.0 standards. The multi-criteria scheme has been implemented using the Fuzzy Analytical Hierarchical Process method (FAHP). The FAHP approach uses fuzzy sets and structural hierarchy analysis. Requirements impose by the Industry 4.0 standards in Mass Customized production can be applied in the food industry.

The Construction Cost Model (COCOMO) works on principles of multi-layer reverse neural network and it is used to estimate costs for the purpose of managing software projects. The model takes into account all necessary resources in order to estimate the costs of the software product, its size, etc [2].

Product rework and transformation at the stage of its development has proven to be very important for 
sustainable production and the extension of the product life cycle. Holistic decision support tool (DRRA), which specifically takes into account four aspects: choice of materials, way of processing, design structure and final product surface processing is presented [3]. Design for remanufacturing is often not compatible with other Design For Excellence (DFX) methods. The Design for Remanufacturing method (DfRem) is accepted in the product development stage.

Product sustainability optimizes the product's design and improves its quality. Concept of product sustainability in relation to the demand in the market takes into account the life cycle theory [4]. The proposed concept begins with the application of the Analytical Hierarchical Process method (AHP), followed by the Technique for Order Preference by Similarity to Ideal Solution design selection method (TOPSIS). Product sustainability is the basis for improving product design.

The concept of discrete multifunctional optimization for determining the minimum product costs is presented according to [5]. In this example, eleven input dimensions for the analyzed products were taken into account, and the cost function included: initial costs, costs of development, use, maintenance and installation costs.

The problems of estimating the costs of software projects and point out that there is a group of researchers who could evaluate the costs of these projects using the mathematical method of multicriteria linear regression and new techniques such as Genetic Algorithms (GA) and Artificial Neural Networks (ANNs) are considered in this paper [6]. The aim is to increase product quality and simultaneously reduce costs. The authors believe that models for estimating the cost of software projects are adapted and linked to new technologies.

Authors [7] of the observed paper point out that product design can be influenced at an early stage of development. In the preliminary and conceptual design stage, a comprehensive analysis of technical and economic requirements which are related to the product is carried out. ANN structures are used to connect product information in relation to the environmental impact.

There is a discussion about relationships in which product development is directly related to global trends in technological development [8]. The attention should be particularly focused on product development and design, since it is very important for production, use, removal and recycling [9], [10]. Bearing in mind that the price, functionality, quality and attractiveness of products are determined at the product development stage [11], [12], [13].

In the framework of innovative development of production systems, authors [14] point to the importance of fuzzy information they use to develop products and plan production processes.

There is importance of supporting the life cycle of complex products, hence also the development phases, based on fuzzy set theory and hierarchical analysis. In the uncertain environment of the production process, expert knowledge is used to create strategic decisions [15].

In this paper, the Adaptive Neural Fuzzy Inference System model was used as a method for estimating development costs of a double-row ball bearing with angular contact. Bearing in mind the importance of managing the target costs, i.e. development and production costs in the product development stage, a flowchart has been set up for the application of the hybrid model for managing the cost of product life cycle [16] with specific focus on the target costs management in this paper.

\section{PRODUCT LIFE CYCLE COST MANAGEMENT}

Managing the costs by using Adaptive Neural Fuzzy Inference System - ANFIS model at the development stage of a product, according to the developed model [17], enables cost management at all stages of the life cycle such as the stage of development, manufacture, use and recycling, as shown in the flow diagram, figure 1 , which is characterized by two basic stages. In the paper [17], a hybrid lifecycle cost management model for a single-row ball bearing has been presented. For the purpose of validating the ANFIS model on a group of similar products, this paper considers the case of a double-row ball bearing with angular contact, which is structurally and technologically more complex than the product used in the above mentioned paper.

The first one refers to the estimation of the lifecycle costs of a new product by using ANFIS model, whereas the other one refers to the process of iterative approximation of the conceptual and preliminary design solution for the new product to the technological manufacturing process whereby the target profit and competitiveness in the market are achieved.

Managing the costs of the life cycle of a new or improved product by using ANFIS model at the development stage of the product is a six-step process. Starting with company's needs or market demand, after the idea has been chosen and the research of the market and manufacturing conditions carried out, the first step involves selecting a product. The second step involves conceptual and preliminary designing and defining the parameters of the new product. The third step is about selecting similar realized products whose life-cycle costs are already known.

Based on the life-cycle costs of similar realized products, the chosen ANFIS model is trained, tested and validated, which is the fourth step of the process. If the accuracy of the ANFIS model training is unsatisfactory, the ANFIS model is trained again. The fifth step involves assessing the life-cycle costs of the observed product based on the trained ANFIS model and the adopted relevant product parameters. The sixth step in the flow diagram is product validation, the process which is based on the set target profit, market price and the costs of use of the competitor's product, as well as the assessed life-cycle costs of the observed product. 


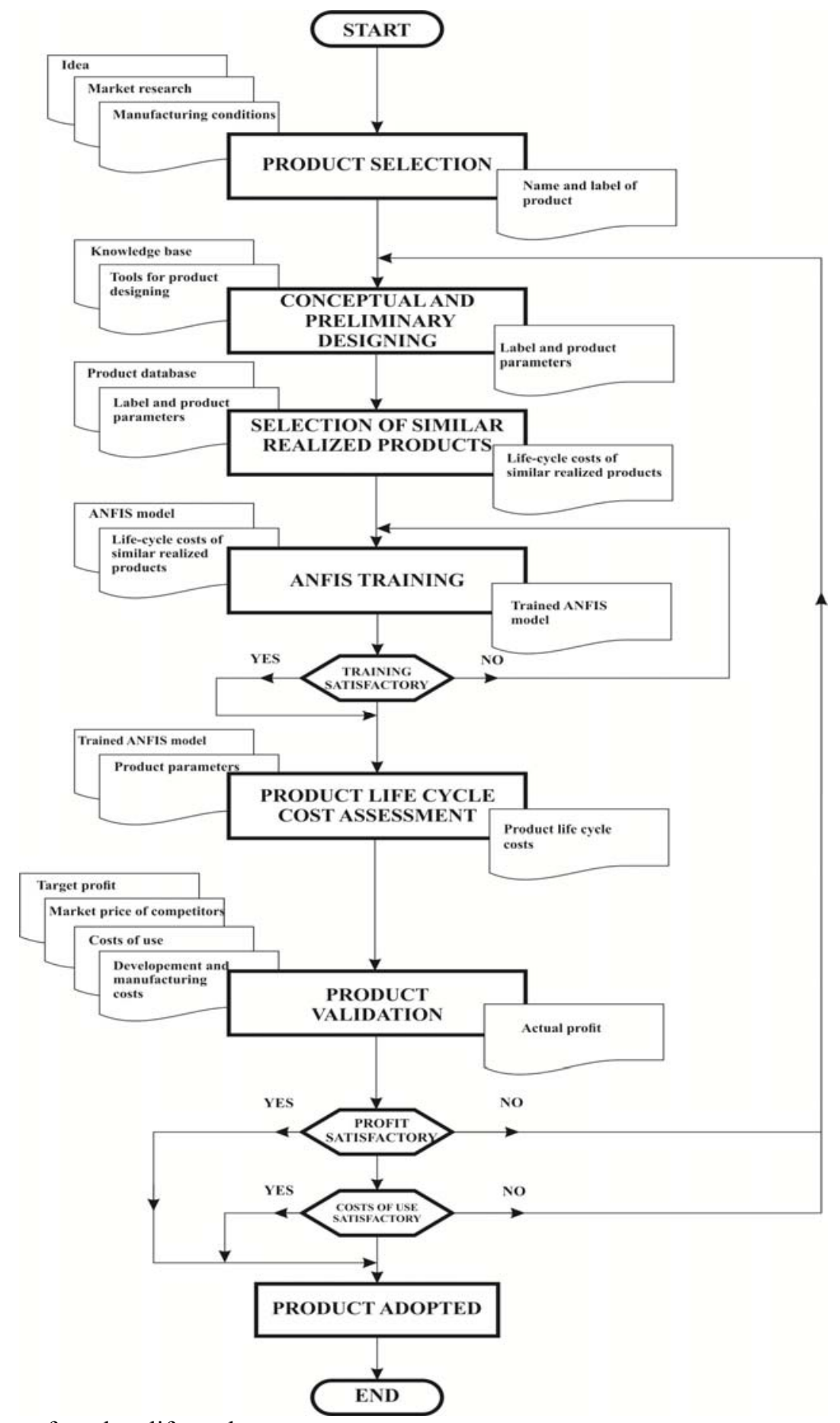

Fig. 1. Flow diagram of product life cycle cost management

\subsection{Managing the target costs of a new product}

Validation of the new product which is created in the phase of conceptual and preliminary design development is based on the target profit. Since it is the market price (CT) and development and manufacturing costs $($ Tra + Tpr) that determine the actual profit $(\mathrm{P})$, the solution for the conceptual and preliminary design of the new product is actual profit either greater or equal to the target profit. Actual profit is determined as:

$$
P=C_{T}-\left(T_{r a}+T_{p r}\right)
$$

In the case when target profit is not achieved within the development and manufacturing costs $\left(\mathrm{T}_{\mathrm{ra}}+\mathrm{T}_{\mathrm{pr}}\right)$ of the observed solution for the new product, the conceptual and preliminary product design is changed or the existing one improved, or a new manufacturing process is developed. In cost management, apart from primary management which refers to managing target costs, i.e., the development and manufacturing costs which provide the target profit, the costs of use are also managed in the way that the costs of use of the observed product are compared to the corresponding costs of use of the competitor's product.

Likewise, in the process of cost management of a product life cycle, apart from the condition in (1), generally, the conceptual and preliminary solution for the new product design that will be adopted will be the one with the lowest recycling costs. As already stated, the concept of cost management of a product life cycle by using ANFIS model is based on the cost 
management of individual stages of the life cycle.

In this paper, in accordance with flow diagram, the cost management of development and production stage is shown, that is management of target costs of selected new product, which ensure the target profit in the market.

\section{CASE STUDY RESULTS}

The case study presents the application of the ANFIS model, according to the flow diagram in figure 1 , for estimating the costs of developing a double-row ball bearing with angular contact. The selected product is specific because it requires meeting the standards for this kind of product, both in terms of material choice and the aspect of technology required for the production.

The case study presents a group of similar ball bearings required to train the network and evaluate the development costs of this product in accordance with the ANFIS model. In addition to the estimated product development costs, the next stage includes the production costs and the estimation of product profitability in relation to the corresponding competitive product.

\subsection{Target cost management in the manufacture of double-row angular contact ball bearings}

Management of target costs in the product development stage involves gradually approximation of conceptual and preliminary product design solution, which provide targeted profit on the market. Given the structural and technological complexity of the product which is the subject to the standards of the industry, the target production costs can be managed, i.e. they can be reduced by investing in technological equipment that will ensure the company's survival and competitiveness in the market.

Management of target costs in the developed model, whose flow diagram of development and application is shown in figure 1, is demonstrated on the selected example of a double-row ball bearing with angular contact. In the observed company which specializes in the manufacture of ball bearings, the installed manufacturing equipment enables production expansion with this kind of product, including doublerow angular contact ball bearings, figure 2 , with a new range of dimensions presented in table 1, for which there is a possibility of distribution in the market.

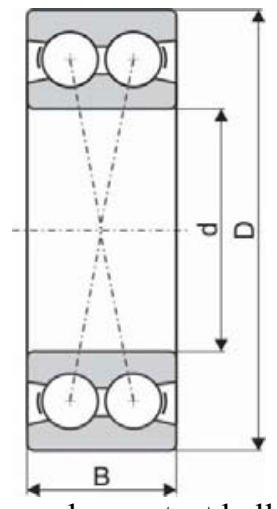

Fig. 2. Double-row angular contact ball bearing
The design solution for this bearing was determined by the requirements of the customers and the standards for this kind of product, with relevant parameters such as bore diameter(d), outer diameter(D), width (B) and mass $(\mathrm{m})$ of the bearing. In addition to the presented product, the given company produces four more structurally and technologically different types of bearings. These are single-row radial ball bearings, single-row cylindrical bearings, single-row spherical bearings and single-row needle bearings in several different dimensions.

The aforementioned relevant parameters of observed products are determined in accordance with the second step of the flow diagram in figure 1.

\begin{tabular}{|c|c|c|c|c|c|}
\hline \multirow{2}{*}{ No. } & \multicolumn{3}{|c|}{ Bearing dimensions and mass } & \multirow{2}{*}{ Label } \\
\cline { 2 - 5 } & \multicolumn{3}{|c|}{$(\mathrm{mm})$} & $\mathrm{kg})$ & \\
\cline { 2 - 5 } & $\mathrm{d}$ & $\mathrm{D}$ & $\mathrm{B}$ & $\mathrm{m}$ & \\
\hline 1. & 30 & 62 & 23.8 & 0.31 & 3206 \\
\hline 2. & 35 & 72 & 27 & 0.48 & 3207 \\
\hline 3. & 40 & 80 & 30.2 & 0.65 & 3208 \\
\hline 4. & 45 & 85 & 30.2 & 0.70 & 3209 \\
\hline 5. & 50 & 90 & 30.2 & 0.74 & 3210 \\
\hline 6. & 55 & 100 & 33.3 & 1.05 & 3211 \\
\hline 7. & 60 & 110 & 36.5 & 1.36 & 3212 \\
\hline 8. & 65 & 120 & 38.1 & 1.76 & 3213 \\
\hline 9. & 70 & 125 & 39.7 & 1.93 & 3214 \\
\hline 10. & 75 & 130 & 41.3 & 2.08 & 3215 \\
\hline
\end{tabular}

Table 1. Dimensions of double-row angular contact ball bearings

\subsection{Selecting a group of similar realized products}

According to the internal classifier of the observed company which specializes in the manufacture of ball bearings, double-row angular contact ball bearings, as a new product, belong to a group of similar bearings from the existing product line-single-row radial ball bearings classified into six type groups [18] with specific range of dimensions and a group of single-row and double-row ball bearings with eighteen different design solutions which are produced in one dimension and used in agricultural machinery[17].

The costs of the development stage of these products, table 2, which include product planning, conceptual design, modelling, structural development, process selection, prototype design, testing the bearing, validation, zero series, etc. are used for training the selected neural fuzzy system as presented in the flow diagram, figure 1 .

The development and manufacturing costs of the selected group of similar bearings include direct and indirect costs of all development activities and manufacturing process activities, including both the costs of the activities and other functions of the company such as company management, marketing, commercial tasks, financial tasks, logistics and human resources, which all together make the manufacturing process possible.

The assessment of these costs, table 2, in the observed company was carried out using adequate methodologies. 


\begin{tabular}{|c|c|c|c|c|c|c|c|}
\hline \multirow{3}{*}{ No. } & \multicolumn{4}{|c|}{ Bearing dimensions and mass } & \multirow{3}{*}{ Label } & \multirow{3}{*}{$\begin{array}{c}T_{\text {ra(E/piece })} \\
\text { Development }\end{array}$} & \multirow{3}{*}{$\frac{T_{p r(\epsilon / \text { piece })}}{\text { Manufacturing }}$} \\
\hline & \multicolumn{3}{|c|}{$(\mathrm{mm})$} & \multirow{2}{*}{$\frac{(\mathrm{kg})}{\mathrm{m}}$} & & & \\
\hline & $\mathrm{d}$ & $\mathrm{D}$ & $\mathrm{B}$ & & & & \\
\hline 1. & 15 & 35 & 11 & 0.04 & 1726202-2RSI & 0.38 & 2.05 \\
\hline 2. & 17 & 40 & 12 & 0.06 & 1726203-2RS1 & 0.31 & 1.69 \\
\hline 3. & 20 & 47 & 14 & 0.10 & 1726204-2RS1 & 0.27 & 1.49 \\
\hline 4. & 25 & 52 & 15 & 0.11 & 1726205-2RS1 & 0.52 & 2.79 \\
\hline 5. & 30 & 62 & 16 & 0.18 & 1726206-2RS1 & 0.28 & 1.56 \\
\hline 6. & 35 & 72 & 17 & 0.25 & 1726207-2RS1 & 0.80 & 4.35 \\
\hline 7. & 40 & 80 & 18 & 0.32 & 1726208-2RS1 & 0.41 & 2.24 \\
\hline 8. & 45 & 85 & 19 & 0.37 & 1726209-2RS1 & 1.13 & 6.14 \\
\hline 9. & 50 & 90 & 20 & 0.41 & $1726210-2 \mathrm{RS} 1$ & 0.56 & 3.06 \\
\hline 10. & 55 & 100 & 21 & 0.56 & 1726211-2RS1 & 1.46 & 7.93 \\
\hline 11. & 60 & 110 & 22 & 0.75 & $1726212-2 \mathrm{RS} 1$ & 1.67 & 9.05 \\
\hline 12. & 65 & 120 & 23 & 0.94 & 1726213-2RS1 & 1.88 & 10.2 \\
\hline 13. & 12 & 40 & 22.1 & 0.09 & UE 203/12 2S & 0.42 & 2.33 \\
\hline 14. & 20 & 47 & 25.5 & 0.11 & UE $2042 \mathrm{~S}$ & 0.40 & 2.20 \\
\hline 15. & 25 & 52 & 27.2 & 0.14 & UE 205 2S & 0.46 & 2.56 \\
\hline 16. & 30 & 62 & 33 & 0.23 & UE $2062 \mathrm{~S}$ & 0.72 & 3.97 \\
\hline 17. & 35 & 72 & 33 & 0.31 & UE $2072 \mathrm{~S}$ & 0.94 & 5.17 \\
\hline 18. & 40 & 80 & 36 & 0.43 & UE 2082 S & 1.18 & 6.48 \\
\hline 19. & 45 & 85 & 37 & 0.48 & UE $2092 \mathrm{~S}$ & 1.30 & 7.18 \\
\hline 20. & 50 & 90 & 38.8 & 0.54 & UE $2102 \mathrm{~S}$ & 1.41 & 7.78 \\
\hline 21. & 12 & 40 & 27.4 & 0.09 & LE 203/12 2F.SH & 0.61 & 3.31 \\
\hline 22. & 25 & 52 & 34.1 & 0.17 & LE $2052 \mathrm{~F}$ & 0.70 & 3.82 \\
\hline 23. & 30 & 62 & 38.1 & 0.28 & LE $2062 \mathrm{~F}$ & 0.61 & 3.37 \\
\hline 24. & 35 & 72 & 42.9 & 0.41 & LE $2072 \mathrm{~F}$ & 1.04 & 5.64 \\
\hline 25. & 40 & 80 & 49.2 & 0.55 & LE $2082 \mathrm{~F}$ & 0.83 & 4.54 \\
\hline 26. & 45 & 85 & 49.2 & 0.60 & LE $2092 \mathrm{~F}$ & 1.40 & 7.52 \\
\hline 27. & 50 & 90 & 51.6 & 0.69 & LE $2102 \mathrm{~F}$ & 1.13 & 6.20 \\
\hline 28. & 55 & 100 & 55.6 & 0.94 & LE $2112 \mathrm{~F}$ & 2.04 & 11.08 \\
\hline 29. & 60 & 110 & 65.1 & 1.30 & LE $2122 \mathrm{~F}$ & 1.95 & 10.75 \\
\hline 30. & 65 & 120 & 68.3 & 1.70 & LE $2132 \mathrm{~F}$ & 3.15 & 17.07 \\
\hline 31. & 70 & 125 & 69.9 & 1.90 & LE $2142 \mathrm{~F}$ & 3.42 & 18.79 \\
\hline 32. & 75 & 130 & 73.3 & 2.10 & LE $2152 \mathrm{~F}$ & 3.85 & 21.19 \\
\hline 33. & 80 & 140 & 77.8 & 2.80 & LE $2162 \mathrm{~F}$ & 6.58 & 35.74 \\
\hline 34. & 85 & 150 & 81 & 3.30 & LE $2172 \mathrm{~F}$ & 4.07 & 22.41 \\
\hline 35. & 90 & 160 & 89 & 4.10 & LE $2182 \mathrm{~F}$ & 10.70 & 58.08 \\
\hline 36. & 100 & 180 & 98.4 & 5.65 & LE $2202 \mathrm{~F}$ & 13.18 & 71.54 \\
\hline 37. & 110 & 240 & 117 & 15.1 & LE $3222 \mathrm{~F}$ & 18.48 & 101.64 \\
\hline 38 & 120 & 215 & 73.5 & 6.20 & LE $2242 \mathrm{~F}$ & 10.60 & 58.29 \\
\hline 39. & 12 & 40 & 28.6 & 0.09 & UY 203/12 2S.SH & 0.65 & 3.52 \\
\hline 40 & 20 & 47 & 31 & 0.11 & UY $2042 \mathrm{~S}$ & 0.71 & 3.87 \\
\hline 41. & 25 & 52 & 31 & 0.14 & UY $2052 \mathrm{~S}$ & 0.55 & 3.03 \\
\hline 42. & 30 & 62 & 35.7 & 0.23 & UY $2062 \mathrm{~S}$ & 0.92 & 5.01 \\
\hline 43. & 35 & 72 & 38.9 & 0.31 & UY $2072 \mathrm{~S}$ & 0.74 & 4.08 \\
\hline 44. & 40 & 80 & 43.7 & 0.43 & UY $2082 \mathrm{~S}$ & 1.36 & 7.40 \\
\hline 45. & 45 & 85 & 43.7 & 0.48 & UY $2092 \mathrm{~S}$ & 1.08 & 5.93 \\
\hline 46. & 50 & 90 & 43.7 & 0.54 & UY $2102 \mathrm{~S}$ & 1.75 & 9.50 \\
\hline 47. & 55 & 100 & 48.4 & 0.98 & UY $2112 \mathrm{~S}$ & 1.53 & 8.40 \\
\hline 48. & 60 & 110 & 53.3 & 1.30 & UY 212 2S & 2.81 & 15.26 \\
\hline 49. & 12 & 40 & 37.3 & 0.162 & LY 203/12 2F & 0.41 & 2.24 \\
\hline 50. & 20 & 47 & 43.7 & 0.19 & LY $2042 \mathrm{~F}$ & 0.63 & 3.44 \\
\hline 51. & 25 & 52 & 44.4 & 0.23 & LY $2052 \mathrm{~F}$ & 0.66 & 3.62 \\
\hline 52. & 30 & 62 & 48.4 & 0.43 & LY $2052 \mathrm{~F}$ & 0.65 & 3.51 \\
\hline 53. & 35 & 72 & 51.1 & 0.68 & LY $2062 \mathrm{~F}$ & 1.13 & 6.12 \\
\hline 54. & 40 & 80 & 56.3 & 0.8 & LY $2072 \mathrm{~F}$ & 1.35 & 7.32 \\
\hline 55. & 45 & 85 & 56.3 & 1.08 & LY $2082 \mathrm{~F}$ & 1.59 & 8.60 \\
\hline 56. & 50 & 90 & 62.7 & 1.44 & LY $2092 \mathrm{~F}$ & 1.89 & 10.22 \\
\hline 57. & 55 & 100 & 71.4 & 1.86 & LY $2102 \mathrm{~F}$ & 2.03 & 11.04 \\
\hline 58. & 60 & 110 & 77.8 & 2.34 & LY $2112 \mathrm{~F}$ & 2.67 & 14.52 \\
\hline 59. & 65 & 120 & 85.7 & 2.95 & LY 212 2F & 3.47 & 18.82 \\
\hline 60. & 70 & 125 & 85.7 & 3.67 & LY $2132 \mathrm{~F}$ & 4.17 & 22.65 \\
\hline
\end{tabular}

Table 2. Development and manufacturing costs of similar products (first part) 


\begin{tabular}{|c|c|c|c|c|c|c|c|}
\hline 61. & 75 & 130 & 92.1 & 4.40 & LY $2142 \mathrm{~F}$ & 4.99 & 27.08 \\
\hline 62. & 80 & 140 & 100 & 2.90 & LY $2152 \mathrm{~F}$ & 6.58 & 35.74 \\
\hline 63. & 90 & 150 & 106 & 3.54 & LY $2162 \mathrm{~F}$ & 7.87 & 42.72 \\
\hline 64. & 100 & 180 & 75 & 4,35 & LY $2202 \mathrm{~F}$ & 7.18 & 39.50 \\
\hline 65. & 110 & 240 & 141.3 & 17.20 & LY 222 FF & 8.58 & 47.19 \\
\hline 66. & 120 & 215 & 81 & 6.70 & LY $2242 \mathrm{~F}$ & 10.60 & 58.29 \\
\hline 67. & 20 & 47 & 34.1 & 0.16 & LN $2042 \mathrm{~F}$ & 0.62 & 3.34 \\
\hline 68. & 25 & 52 & 34.9 & 0.17 & LN $2052 \mathrm{~F}$ & 0.49 & 2.71 \\
\hline 69. & 30 & 62 & 36.5 & 0.30 & LN $2062 \mathrm{~F}$ & 0.83 & 4.48 \\
\hline 70. & 35 & 72 & 37.7 & 0.49 & LN $2072 \mathrm{~F}$ & 0.97 & 5.32 \\
\hline 71. & 40 & 80 & 42.9 & 0.58 & LN $2082 \mathrm{~F}$ & 0.99 & 5.39 \\
\hline 72. & 45 & 85 & 42.9 & 0.66 & UE $2082 \mathrm{~F}$ & 1.18 & 6.48 \\
\hline 73. & 50 & 90 & 42.9 & 0.76 & LN $2092 \mathrm{~F}$ & 1.37 & 7.45 \\
\hline 74. & 60 & 110 & 61.9 & 1.52 & LN $2102 \mathrm{~F}$ & 1.57 & 8.51 \\
\hline 75. & 70 & 125 & 68.2 & 2.25 & LN $2142 \mathrm{~F}$ & 4.37 & 23.71 \\
\hline 76. & 30 & 62 & 30 & 0.39 & FKL 306230 & 0.65 & 3.53 \\
\hline 77. & 35 & 72 & 34 & 0.54 & FKL $357234 \mathrm{~A}$ & 1.01 & 5.45 \\
\hline 78. & 30 & 62 & 23.8 & 0.285 & 3206 B.2RS1 & 0.77 & 4.21 \\
\hline 79 . & 50 & 90 & 51.6 & 0.70 & LE $2102 \mathrm{~TB}$ & 1.19 & 6.49 \\
\hline 80. & 20 & 47 & 20.6 & 0.16 & 3204 B.2RS1 & 0.62 & 3.37 \\
\hline 81. & 20 & 47 & 25.2 & 0.185 & $3204 \mathrm{~T}$ & 0.65 & 3.55 \\
\hline 82. & 30 & 62 & 50 & 0.50 & $5206 \mathrm{KPP} 3$ & 1.33 & 7.22 \\
\hline 83. & 17 & 47 & 24.2 & 0.20 & SL $33032 \mathrm{~S}$ & 0.42 & 2.28 \\
\hline 84. & 16 & 40 & 43.88 & 0.218 & SL 5203 2T & 0.52 & 2.84 \\
\hline 85. & 16 & 45 & 18.67 & 0.23 & $06 \mathrm{C} 04-2 \mathrm{Z}$ & 0.38 & 2.05 \\
\hline 86. & 16 & 40 & 18.29 & 0.08 & Q 203 PP.AH02 & 0.39 & 2.13 \\
\hline 87. & 13 & 40 & 18.29 & 0.091 & Q 203 PP.AH05 & 0.40 & 2.13 \\
\hline 88. & 16 & 53 & 19.4 & 0.28 & SL 5316 2T & 0.60 & 3.28 \\
\hline 89. & 19 & 52 & 21.1 & 0.28 & 205 KRP2 & 0.65 & 3.51 \\
\hline 90. & 60 & 130 & 68.4 & 2.97 & LY $3122 \mathrm{~F}$ & 2.33 & 12.58 \\
\hline 91. & 50 & 81 & 30 & 0.42 & 209 KRR K/50.135 & 1.69 & 9.19 \\
\hline 92. & 38 & 90 & 30 & 0.80 & $210 \mathrm{RRB} 6$ & 2.83 & 15.37 \\
\hline 93. & 31 & 80 & 36.5 & 0.67 & W 208 PPB16 & 2.74 & 14.89 \\
\hline
\end{tabular}

Table 2. Development and manufacturing costs of similar products (second part)

\subsection{ANFIS model of current data}

The development and manufacturing costs of the group of similar realized products, table 2, enabled the training of the selected neural fuzzy system, i.e. ANFIS model which was developed as a hybrid neural fuzzy system using a corresponding software.

The use of artificial neural networks gives good results in solving tasks which are based on experimental data. Their major shortcoming is limited interpretation of results and inability to work with imprecise data. Fuzzy logic is capable of solving tasks based on imprecise data but it cannot independently generate rules for data procession. Adaptive Neural Fuzzy Inference Systems (ANFIS models) represent the synergy of neural networks and fuzzy logic. The ANFIS model is a structured set of parameters that can be modified. The limiting factor of the ANFIS model in terms of configuration is that it should have a feed forward form.

There are three types of fuzzy deduction systems in use - Mamdani, Sugeno and Tsukamoto [19], [20], [21], Therefore, new hybrid models have been developed as an expansion of the possibilities of fuzzy logic and models of artificial neural systems.

\subsection{ANFIS model training}

Before training the selected ANFIS model, the degrees of correlation between input values such as bore diameter (d), outer diameter (D), width (B) and mass $(\mathrm{m})$ and development and manufacturing costs of these bearings from the group of similar products were determined.

The degrees of correlation between the mentioned input values of the chosen similar products and corresponding development costs were $0.89,0.89,0.79$, and 0.85 respectively. The ANFIS model was trained using asymmetric Gaussian function (gauss $2 \mathrm{mf}$ ), with parameters ( $\left(\begin{array}{llll}1 & 3 & 3 & 4\end{array}\right)$. As a result of inaccuracy of the corresponding software, a small number of negative values emerged when testing the ANFIS model that were removed before the development costs of the new product were estimated.

\subsubsection{Training the ANFIS model for estimating development costs}

Training, testing and validation of the mentioned ANFIS model for estimating development costs were performed according to input data and development costs of the selected group which comprises 93 similar bearings. To illustrate this, a graphical representation of the development costs $\left(\mathrm{T}_{\mathrm{ra}}\right)$ is given, depending on the input data which refer to bore diameter (d), outer diameter (D), width (B) and mass (m) of the bearing, figure 3 .

As input variables $D, d, B, m$ referring to the outer diameter (D), hole diameter (d), the width (B) and the 
mass (m) of bearings all affect the costs of product development.

$$
\text { a) } T_{r a}=f(d, D)
$$

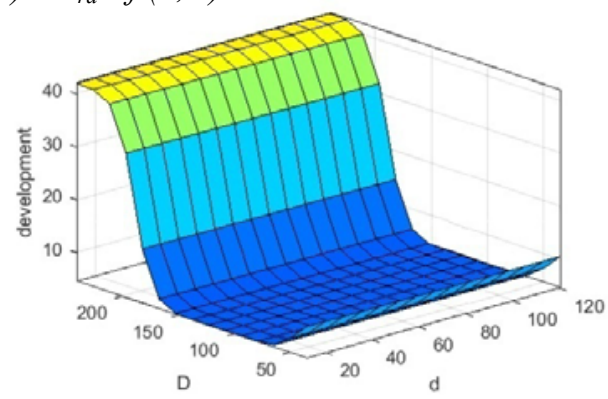

b) $T_{r a}=f(d, B)$

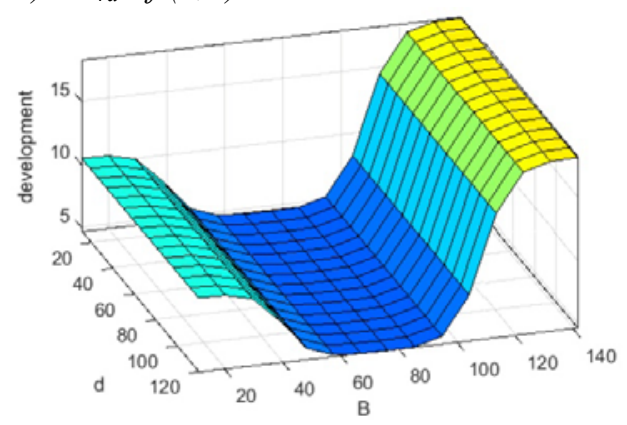

c) $T_{r a}=f(d, m)$

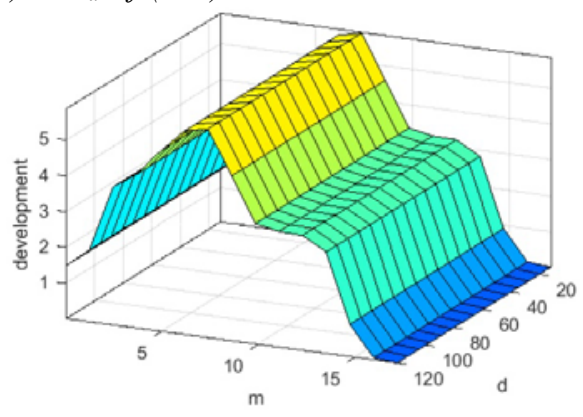

d) $T_{r a}=f(D, B)$

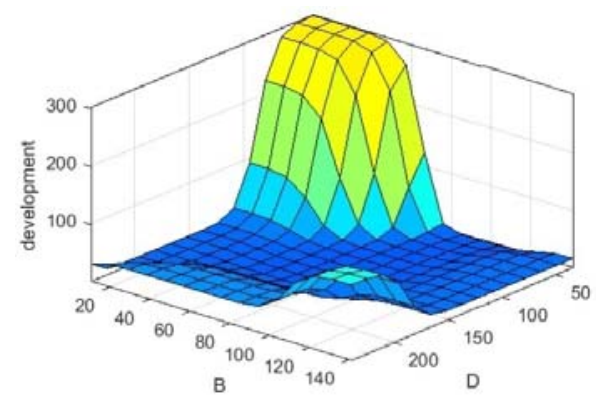

e) $T_{r a}=f(D, m)$

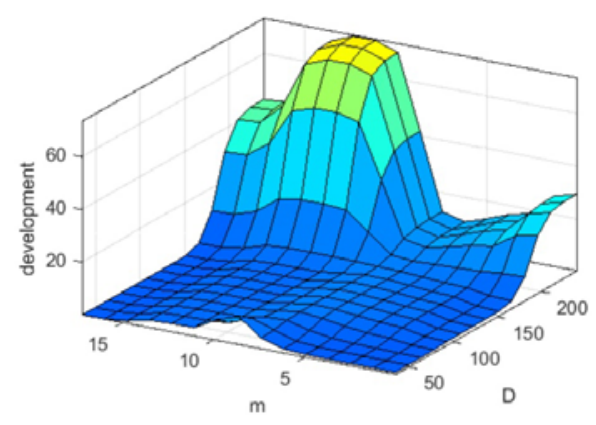

Fig. 3. (a, b, c, d, e) Graphical representation of the development stage costs $\left(\mathrm{T}_{\mathrm{ra}}\right)$
Training, testing and validating the aforementioned ANFIS model was performed for development stage on the basis of corresponding input data and systematized data on the costs of development and production stage of the selected group consisting of 93 bearings, table 2 .

Membership functions (gauss $2 \mathrm{mf}$ ) that was used to obtain the desired output is a combination of two different Gaussian curve, where one side is angled.

The results of training, testing and validation of the mentioned ANFIS model are shown in table 3.

\begin{tabular}{|c|c|}
\hline Error amount & Development \\
\hline Error for 1000 epochs & 0.46128 \\
\hline Training error & $0.46132 \%$ \\
\hline Testing error & $2.2447 \%$ \\
\hline Validation error & $0.31506 \%$ \\
\hline
\end{tabular}

Table 3. The results of training, testing and validation of the selected ANFIS model

Based on the input data for the selected group of realized similar bearings, table 2 , the degrees of correlation of inputs bearings were determined referring to the bore diameter (d), outer diameter (D), width (B) and mass (m) and the bearing's costs by development stage.

Thus, it can be concluded that there is a high degree of correlation between the aforementioned input dimensions of the selected group of bearings and the costs of the development stage, table 3 .

\subsection{The estimation of development and manufacturing costs of the new product}

The development and manufacturing costs of double-row angular contact ball bearings were assessed using the trained ANFIS model and adequate input data (d, D, B, m), table 4.

Based on the obtained values of the development and production costs, the profit (measured in euro/piece) is determined as the difference between market price of a competitor's product and the sum of the development and production costs. The production costs $\left(T_{\text {pr }}\right)$ of double row ball bearings, table 4 , were determined using a corresponding trained ANFIS model, which was trained based on data for production costs of a selected group of similar realized products, table 2, [17].

\subsection{The assessment of the new product profitability}

For market prices of the observed group of doublerow angular contact ball bearings $\left(\mathrm{C}_{\mathrm{T}}\right)$, which are determined by a corresponding competitor's product in the domestic market, actual profit for individual dimensions of the bearings was assessed by using the expression (1), table 5 .

The desired profitability can be achieved by managing the target costs based on the reduction of development and production costs, which means changing the design and improving the production process. 


\begin{tabular}{|c|c|c|c|c|c|c|c|}
\hline \multirow{2}{*}{ No. } & \multicolumn{3}{|c|}{ Bearing dimensions and mass } & \multirow{2}{*}{ Label } & \multirow{2}{*}{ Development } & \multirow{2}{*}{ Manufacturing } \\
\cline { 2 - 4 } & \multicolumn{3}{|c|}{$(\mathrm{mm})$} & $\mathrm{kg})$ & $T_{\text {ra }}($ E/piece $)$ & 0.69 & $T_{\text {pr }}($ E/piece $)$ \\
\hline 1. & $\mathrm{~d}$ & $\mathrm{D}$ & $\mathrm{B}$ & $\mathrm{m}$ & & 3.83 \\
2. & 35 & 62 & 23.8 & 0.31 & 3206 & 1.12 & 6.31 \\
3. & 40 & 80 & 30.2 & 0.65 & 3207 & 2.00 & 11.20 \\
4. & 45 & 85 & 30.2 & 0.70 & 3208 & 2.25 & 12.50 \\
5. & 50 & 90 & 30.2 & 0.74 & 3210 & 2.31 & 20.00 \\
6. & 55 & 100 & 33.3 & 1.05 & 3211 & 3.85 & 23.30 \\
7. & 60 & 110 & 36.5 & 1.36 & 3212 & 4.52 & 26.40 \\
8. & 65 & 120 & 38.1 & 1.76 & 3213 & 4.69 & 26.30 \\
9. & 70 & 125 & 39.7 & 1.93 & 3214 & 4.44 & 26.20 \\
10. & 75 & 130 & 41.3 & 2.08 & 3215 & 5.12 & \\
\hline
\end{tabular}

Table 4. Development and manufacturing costs of double-row angular contact ball bearings

\begin{tabular}{|c|c|c|c|c|c|c|c|c|}
\hline \multirow{3}{*}{ No. } & \multicolumn{4}{|c|}{ Bearing dimensions and mass } & \multirow{3}{*}{ Label } & & \multirow{2}{*}{$T_{r a+} T_{p r}$} & \multirow{2}{*}{$C_{T^{-}}\left(T_{r a+} T_{p r}\right)$} \\
\hline & \multicolumn{3}{|c|}{$(\mathrm{mm})$} & $(\mathrm{kg})$ & & $\mathrm{C}_{T}$ & & \\
\hline & $\mathrm{d}$ & $\mathrm{D}$ & $\mathrm{B}$ & $\mathrm{m}$ & & \multicolumn{3}{|c|}{$(€ /$ piece $)$} \\
\hline 1. & 30 & 62 & 23.8 & 0.31 & 3206 & 4.93 & 4.52 & 0.41 \\
\hline 2. & 35 & 72 & 27 & 0.48 & 3207 & 7.88 & 7.43 & 0.45 \\
\hline 3. & 40 & 80 & 30.2 & 0.65 & 3208 & 13.72 & 13.20 & 0.52 \\
\hline 4. & 45 & 85 & 30.2 & 0.70 & 3209 & 15.46 & 14.75 & 0.71 \\
\hline 5. & 50 & 90 & 30.2 & 0.74 & 3210 & 15.81 & 15.01 & 0.80 \\
\hline 6. & 55 & 100 & 33.3 & 1.05 & 3211 & 24.16 & 23.85 & 0.31 \\
\hline 7. & 60 & 110 & 36.5 & 1.36 & 3212 & 28.28 & 27.82 & 0.46 \\
\hline 8. & 65 & 120 & 38.1 & 1.76 & 3213 & 32.30 & 31.09 & 1.21 \\
\hline 9. & 70 & 125 & 39.7 & 1.93 & 3214 & 31.81 & 30.74 & 1.07 \\
\hline 10. & 75 & 130 & 41.3 & 2.08 & 3215 & 32.17 & 31.32 & 0.85 \\
\hline
\end{tabular}

Table 5. Asessment of profitability of the observed bearing group

\section{CONCLUSION}

Managing target costs by using a ANFIS model at the development stage of a product enables evaluation of alternative design solutions for the new product, as well as adopting the most economical manufacturing process by which satisfactory product profitability is achieved.

Since the changes of the design and material for the manufacture of the observed bearings, with the aim of reducing manufacturing costs are not possible because of functional and standard requirements for this kind of product, the increase in profitability in the manufacture of these bearings in the observed company can be achieved by improving the existing manufacturing process or introducing a new, more efficient manufacturing process with lower target costs.

Target cost management is extremely important, especially at the development stage, since it is in response to the feedback from the market that the directions for improvement of the realized products are determined, in accordance with market demand.

The presented possibility of using ANFIS model in target cost management at the development stage of a product raises awareness of the company about the importance of collecting, systematization and development of a database of development and manufacturing costs of the realized products.

The trained ANFIS model for certain groups of similar realized products from the existing product line, for which development and manufacturing costs are already known, are an important knowledge base of the observed company.

According to the given flow diagram, it is also possible to apply management of target costs model on products in the construction industry, textile industry, electronic industry, and industry of furniture production. Managing target costs in other branches of industry means applying the ANFIS model using data on a group of similar, realistic products that will be used to analyze the development costs of a new product for which these costs were estimated. The sum of development costs and production costs represents the product costs, which, as shown, provide profit when compared with the market price of the competing product.

\section{REFERENCES}

[1] Simon, J., Trojanova, M., Zbihlej, J., Sarosi, J., 2018, Mass customization model in food industry using Industry 4.0 standard with fuzzy-based multi-criteria decision making methodology, Advances in Mechanical Engineering, 10, pp. 110.

[2] Arora, S., Mshara, N., 2018, Software cost estimation using artificial neural network, Advances in Intelligent Systems and Computing, 584, pp. 51-58.

[3] Yang, S. S., Ong, S. K., Nee, A. Y. C., 2016, A Decision Support Tool for Product Design for Remanufacturing, Procedia CIRP, 40, pp. 144149.

[4] Xiaogang, J., Shuaibo, C., Qianfeng, C., 2017, A study on the evaluation of the product maintainability based on the life cycle theory, Journal of Cleaner Production, 141, pp. 481-491.

[5] Sarma, K. C., Adeli, H., 2002, Life-cycle cost 
optimization of steel structures, International Journal for Numerical Methods in Engineering, 55, pp. 1451-1462.

[6] Briciu, C. V. F., Indries, I.I., 2008, Methods for cost estimation in software project management, IOP Conference Series: Materials Science and Engineering.

[7] Visotsky, D., Patel, A., Summers, J., 2017, Using Design Requirements for Environmental Assessment of Products: A Historical Based Method, Procedia CIRP, 61, pp. 69-74.

[8] Katila, R., Ahuja, G., 2002, Something Old, Something New: A Longitudinal Study of Search Behavior and New Product Introduction, Academy of Management Journal, 45, pp. 118394.

[9] Wenzel, H., Hauschild, M. Z., Alting, L., 2000, Environmental Assessment of Products. Springer Science \& Business Media. Springer

[10] Rayate, V., Summers, J. D., 2012, Representations: Reconciling Design for Disassembly Rules with Design for Manufacturing Rules, International Design Engineering Technical Conferences and Computers and Information in Engineering Conference, ASME, Chicago, Paper No. DETC2012-70987, pp. 369-379.

[11] Pahl, G., Beitz, W., 2013, Engineering Design: A Systematic Approach, Springer Science \& Business Media.

[12] Akao, Y., 2004, QFD: Quality Function Deployment - Integrating Customer Requirements into Product Design, Taylor \& Francis.

[13] Hoover, C. W., Jones, J. B., 1991, Improving Engineering Design: Designing for Competitive Advantage, Washington, D C: National Academies Press

[14] Steimer, C., Cadet, M., Aurich, J. C., Stephan, N., 2016, Approach for an integrated planning of manufacturing systems based on early phases of product development, Procedia CIRP, 57, pp. 467 -472 .

[15] Zakharova, A. A, Kolegova, O. A., Nekrasova, M., Eremenko, E. A. Y. O., 2016, Methods Used to Support a Life Cycle of Complex Engineering Products, IOP Conference Series: Materials Science and Engineering, 142 (1) 012107.

[16] Todić, V., Ćosić, I., Maksimović, R., Tasić, N., Radaković, N., 2016, Model for simulation of life cycle costs at the stage of product development, International Journal of Simulation Modelling, 16 (1), pp. 108-120.

[17] Todić, V., 2016, Hybrid model of product lifecycle cost management, $\mathrm{PhD}$ Thesis, University of Novi Sad, Faculty of Technical Sciences, Serbia.

[18] Mitrofanov, S. P., 1976, Naučnaja organizacija mašinostrojiteljnova proizvodstva, Mašinostrojenije, Lenjingrad.

[19] Mamdani, H. E., Assilian, S., 1975, An experiment in linguistic synthesis with a fuzzy logic controller, International Journal of ManMachine Studies, 7 (1), pp. 1-13.

[20] Sugeno, M., Kang, G. T., 1988, Structure identification of fuzzy model, Fuzzy sets and Systems, 28, pp. 15-33.

[21] Tsukamoto, Y., 1979, An approach to fuzzy reasoning method (Advances in fuzzy set theory and applications, edited by Yager Amsterdam: Elsevier), 137-149 p.

Authors: Science Associate Vladimir Todić PhD, Professor Rado Maksimović PhD, Professor Ilija Ćosić PhD, University of Novi Sad, Faculty of Technical Sciences, Department of industrial engineering and engineering management, Trg D. Obradovica 6, 21000 Novi Sad, Serbia, Phone.: +381 21 485-297.

E-mail: vladimir.todic@uns.ac.rs rado@uns.ac.rs ilijac@uns.ac.rs

Note: This research (paper) has been supported by the Ministry of Education, Science and Technological Development through the project no. 451-03-68/2020-14/200156: "Innovative scientific and artistic research from the FTS (activity) domain". 